\title{
Research on the Development Mode of "Three New" Led Building Electricity and Intelligence Specialty
}

\author{
ZHOU Xueyan, LIAO Jixiang, SUN Boling, LUO Qiubin and LIN Zehong \\ College of Engineering, Harbin University, 150086
}

\begin{abstract}
New engineering has brought a development opportunity for the specialty development of local applied universities. Since building Electricity and Intelligence Specialty is an emerging inter-discipline, the paper analyzes the present development of applied universities at home and abroad and the professional talent demand, and then based on the analysis, the paper also combines with the current status of Building Electricity and Intelligence Specialty in Harbin University, and puts forward the development mode of "three new" led Building Electricity and Intelligence Specialty, so as to accelerate the cultivation of much-needed professionals who can serve the local community.
\end{abstract}

Keywords-New engineering; "three new"; Applied universities; Specialty development mode

\section{INTRODUCTION}

In order to promote engineering education reform innovation, on February 18, 2017, the Ministry of Education convened higher engineering education development strategic seminar at Fudan University, and discussed several problems such as the containing characteristics of new engineering, the construction of new engineering and the selection of development path [1]. After that, the Ministry of Education published the Notice of the Department of Higher Education for the Ministry of Education about Carrying out the Research and Practice of "New Engineering" and it is hoped that universities of all places can carry out the research and practical activities of "New engineering". The new engineering corresponds to the emerging industry, and firstly, it is specific to the specialty of emerging industry, such as artificial intelligence, smart manufacturing, robot, and cloud computer, and also includes the upgrading and transformation of traditional engineering specialties [2]. In the Notice, the main contents of new engineering are summarized as "Five-new", i.e., the new concept of engineering education, the new structure of discipline and specialty, the new mode of talent cultivation, the new quality of education teaching and the new system of classified development[3]. On April 8, 2017, the Ministry of Education convened the new engineering construction seminar at Tianjin University, and above 60 universities jointly discussed the vision and action for new engineering construction. The Ministry of Education prepared to carry out the research from three types of universities, including the engineering advantage universities, comprehensive universities and local universities, of which the local applied universities are generally directly subordinated to provincial and municipal levels, and take applied type as the school-running orientation, rather than the undergraduate higher universities taking scientific research as the schoolrunning orientation. Such universities need to use the local resources, dock with the development demand of local economic society and the enterprise technology innovation requirements, deepen the integration of production and education, school-enterprise cooperation, collaborated talent cultivation, promote the transformation and upgrading of traditional engineering, carry out the research and practice of new engineering in local universities [4-5].

Up till 2020, the new generation of information technology industry, electronic equipment, high-grade CNC machine tools, robots and new materials will become specialties with the biggest talent gap, of which the talent gap for the new generation of information technical industry will reach to 7,500,000 people. Up till 2025, the talent gap for the new generation of information technology industry will reach to 9,500,000 people, and the talent gap for electronic equipment will reach to above 9 million people [6-7]. In combination with the actual development conditions of our school, we had made declaration for two times in 2014 and 2015 respectively, and finally obtained the approval of the Building Electricity and Intelligence Specialty, and the specialty is integrated with civil engineering, electronics, computer and other specialty characteristics, and then in 2016, it officially started to recruit students, and currently, there are 104 students at school. The Building Electricity and Intelligence Specialty belongs to new cross-discipline specialty, and there are merely 89 universities nationwide setting the specialty, and most of them are distributed at Jiangsu and Zhejiang areas, and within Heilongjiang Province, there are only two universes, including Harbin Institute of Technology and Harbin University, and the school-running orientations are different, Harbin Institute of Technology mainly cultivates scientific research talents, and most graduates cannot directly supply the development of local economic society. The bidding and recruitment of the specialty are based on the original intention of serving the development of local economic society, and belong to a major measure for the development of new engineering, so it is still worth studying how to operate the specialty. 


\section{CURRENT RESEARCH StATUS AT HOME AND ABROAD}

The construction of characteristic applied undergraduate universities is one of the important projects for Heilongjiang to execute the Construction Plan for Constructing a Province with a Powerful Higher Education, and after the talents cultivated thereby complete their studies, most of them will be directly employed, so the main cultivation objective for these universities is how to combine market demand, and provide high-quality talent supply to the society.

The fast development of new engineering has absorbed the international experience for the development of new economy abroad, and taken the American development course as the example; in 1970s, microelectronics, computer technology, program-controlled exchange and the internet were expanded to the overall economic entity until 1990s, and the delay therein was quite clear. Since talent cultivation requires certain time to adapt to the new technology and new industrial development, the knowledge and skills of talents requested for the information industry cannot be solved through simple training, and it requires the entire education system to make corresponding adjustment. American higher education system was started from the beginning of 1970s, and used above 20 years of time to adapt to the talent resource transformation demand incurred by information technology reform, and also completed the after-war higher education structural reform itself, and generated benign interaction with American new economy. After the outbreak of the financial crisis in 2008, America executed "Reindustrialization" strategy. In July, 2009, American Manufacturing Industry Alliance published the report called Creating a Better Future for America, and requested the government to adopt measures from trade policy, skill training, investment $R \& D$ and other aspects to protect the development of manufacturing industry, and American engineering education corresponded to the strategy [8].

At home, we have the world's largest scale of engineering education. In 2016, there were 5,380,000 engineering undergraduate students at school, 1,230,000 graduates, 17,037 specialty layouts, and the engineering students at school can occupy about 1/3[9] of the total students at school for higher education. The quality of engineering education has decided the overall quality of higher education in our country to a great extent. But at the current period when traditional specialty employment is difficult, the status of no available counterpart talents for emerging industry is quite common. It can be easily seen from the series of measures of the Ministry of Education, the basic requirement for our country to deepen education reform is to positively develop "new engineering", while the new engineering reform of local undergraduate universities will serve the local economy more directly [10]. The Building Electricity and Intelligent Specialty has been set in 89 universities nationwide, and within Heilongjiang Province, there are merely Harbin Institute of Technology and our school setting this specialty, and Harbin Institute of Technology mainly cultivates research-type talents, and will not directly import them to the talent market, so the talent gap for the specialty is huge, and currently, the freshmen and sophomores at school are almost fully "booked". Meanwhile, our school has the soil to develop Building Electricity and Intelligent Specialty, and all the resources and talents of Civil Engineering Specialty, Urban Underground Space Specialty, Computer Science and Technology Specialty and Electronic Information Engineering Specialty are the effective assistance for the development of Building Electricity and Intelligent Specialty. Thus, the problem demanding prompt solution is how to build characteristic new engineering talent cultivation research about Building Electricity Specialty in local universities and radiate to talent cultivation scheme and course system.

\section{THE DEVELOPMENT MODE OF “THREE NEW" CREATING ELECTRICITY AND INTELLIGENCE SPECIALTY}

"New engineering" has brought new opportunities for the development of local undergraduate universities. On one hand, local universities effectively sort out the existing specialty configuration, make an overall arrangement for the construction of strategic emerging industry related specialties, and use new specialties to activate traditional specialty; on the other hand, new characteristic specialties should further define talent cultivation objective, and formulate sounder course system, to serve the development of local economic society; meanwhile, it is also requested to build sound specialty laboratory, internship and practical training base, so as to improve students' practical capacity; meanwhile, take employment as the orientation, combine the current status about the local enterprises, and accelerate the cultivation of urgently needed professional talents.

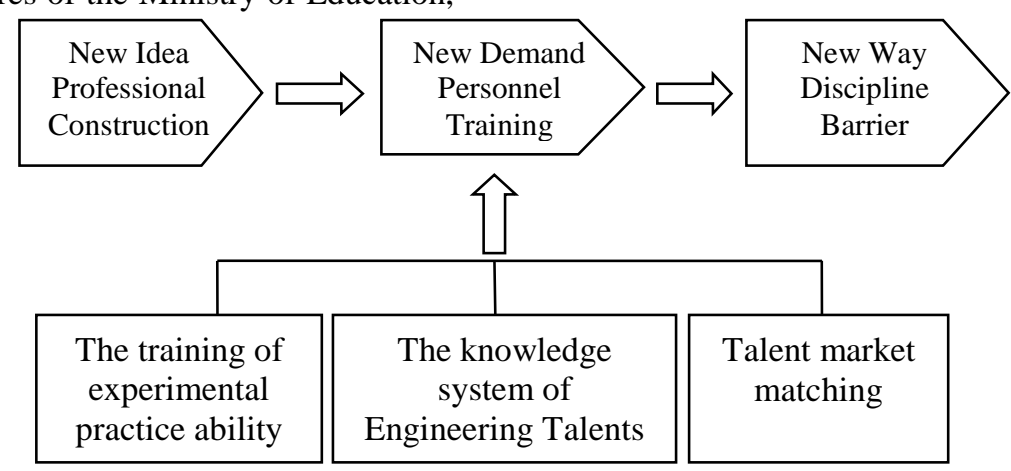

Fig. 1. The Development Mode of “Three New” Led Building Electricity and Intelligence Specialty 


\section{2) Broaden Engineering Talent Knowledge System}

Building Electricity and Intelligence Specialty is overlapped with Civil Engineering, Urban Underground Space, Electronic Information Engineering, Computer Science and Technology and Automation and other specialties, so there should be emphasized development direction in college structure, and as for the teachers, it has been equipped with many professional teachers, and as for the setup of practical link, it will realize highly sharing with Harbin Metro Group, Harbin Property Heat Supply Group Co., Ltd., Shanghai Liangxin Electrical Co., Ltd., Heilongjiang Haobainian Construction Engineering Co., Ltd., and brother universities.

Specifically speaking, under the construction background of "new engineering", the new Building Electricity and Intelligence Specialty should break through discipline barriers, expand engineering talent knowledge, integrate specialty barriers, build big engineering concept for engineering talents, and provide more professional and composite talents for the development of regional economy.

\section{3) Smooth Engineering Talent Market Matching}

Talent cultivation should be positioned in the market demand, and on this basis, the new Building Electricity and Intelligence Specialty should build sound school-enterprise jointly built specialty laboratories, to promote students' practical capacity, post core capacity; and focus on students' comprehensive quality cultivation, the cultivation of lifelong learning capacity, and cultivate engineering applied talents with craftsman spirits; so as to compensate for schoolenterprise barriers, and further smoothen engineering talent market matching.

\section{C. "New Approach" Breaks Through Discipline Barriers, and Cultivates Innovative Talents Serving the Local}

The "New approach" conducts the new engineering talent cultivation through inheritance and innovation, intersection and integration as well as coordination and sharing. In the future, what the emerging industry and new economy requires is highquality and composite "New engineering" talents with strong engineering practice capacity and strong innovation capacity. Specifically speaking, under the construction background of "New engineering", it is requested to transport talents with "cross-discipline and integration" characteristics to the employment market, and as for the specialties, it is requested to set specialty-oriented course groups as per the employment requirements of the Metro Group and the Heat Supply Group, which can be good for the zero-interface employment of students.

It can then radiate the entire college, and as for the existing engineering specialties, it is requested to further define talent cultivation objective, formulate the course system serving the development of local economic society, and provide practical references to the engineering course system construction and specialty operation mechanism research of applied universities; on the other hand, specialties can break the discipline barriers through close integration, and then hatch new specialties serving the local. 


\section{CONCLUSION}

This paper mainly studies the current status and coping strategies about the transformation development of local undergraduate universities under the background of new engineering. Specific to new cross-discipline specialties, it puts forward the development mode research of "Three new" led Building Electricity and Intelligence Specialty, it has broken through the current status of "Similar cultivation of thousands schools" in local applied universities, taken the service of local economy as the characteristics, prepared to formulate "Several times of school-enterprise alternating practical teaching mode", emphasized on the in-depth cooperation of school and enterprises, and through the teaching mode of "Theorypractice-theory-re-practice", broken through professional barriers and transported composite engineering talents for local economy.

\section{ACKNOWLEDGMENT}

Fund Assistance: It is supported by Heilongjiang Province Educational Scientific Planning Key Project (GBB1318063), Heilongjiang Province Educational Scientific Planning Project (GJC1316149) and the 13th Five-year Higher Education Scientific Research Project (16Q170, 16Q172).

\section{Author:}

ZHOU Xueyan (1981.8-), female, the Associate Professor and Doctor majoring in Building Electricity and Intelligence Specialty for the Engineering College of Harbin University, and the main research direction is social computing, and higher education research.

\section{REFERENCES}

[1] WU Aihua, HOU Yongfeng et al. Accelerate the Development and Construction of New Engineering, Actively Adapt to and Lead the New Economy [J]. Researches in Higher Education of Engineering, Period 1, 2017

[2] ZHU Jun, SONG Shuxiang et al. Basic Practical Teaching Reform for Electronic Information Specialty of "New Engineering" Innovation Concept [J]. Experimental Technology and Management, 2017, 34 (11): 171-173+177

[3] LI Deyi and MA Nan. New Engineering of the Smart Era-Artificial Intelligence Promotes the Practice of Education Reform [J]. Researches in Higher Education of Engineering, 2017, (05): 8-12.

[4] ZHAO Ji and XIE Yinbo. New Engineering Construction and Engineering Education Innovation [J]. Researches in Higher Education of Engineering, 2017, (05): 13-17+41.

[5] LIN Jian. Deeply and Solidly Promote the Construction of New Engineering - the Organization and Implementation of New Engineering Research and Practice Project [J]. Researches in Higher Education of Engineering, 2017, (05): 18-31.

[6] ZHANG Haisheng. Background, Value Orientation and Expected Result about the Construction of "New Engineering" [J]. Hubei Social Sciences, 2017, (09): 167-173.

[7] JIANG Zongli. Computer Specialty Reform under the Construction Background of the New Engineering [J]. China University Teaching, 2017, (08): 34-39

[8] SHI Xiaoqiu, ZHAO Yan and LI Xiaokun. Reflections about the Integrated, Opened and Self-adaptive New Engineering System Construction in Local Universities [J]. Researches in Higher Education of Engineering, 2017, (04): 10-15

[9] XU Xiaofei and DING Xiaohua. Exploration about the Reform of New Engineering Talent Cultivation Mode Oriented to Sustainable Competiveness [J]. China University Teaching, 2017, (06): 6-10.

[10] XIA Jianguo and ZHAO Jun. Rustic Opinions about the Engineering Education Reform Development of Local Universities under the construction Background of the New Engineering [J]. Researches in Higher Education of Engineering, 2017, (03): 15-19+65. 